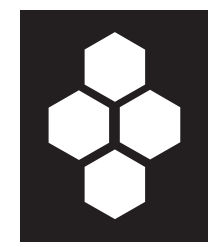

\title{
Agglomeration and the spatial distribution of creativity
}

\author{
Roland Andersson ${ }^{1}$, John M. Quigley ${ }^{2}$, Mats Wilhelmsson ${ }^{1}$ \\ ${ }^{1}$ Royal Institute of Technology, S 10044 Stockholm, Sweden (e-mail: rolanda@infra.kth.se; \\ matsw@infra.kth.se) \\ ${ }^{2}$ University of California, Berkeley, California USA 94720 (e-mail: quigley@econ.berkeley.edu)
}

Received: 1 April 2005 / Accepted: 2 June 2005

\begin{abstract}
This article analyses the spatial distribution of "creativity" - the production of new knowledge. We analyse commercial patents granted in Sweden between 1994 and 2001 using a panel of 100 labour market areas that encompass the entire country. We relate patent activity to measures of localisation and urbanisation, to the industrial composition and size distribution of firms, and to the regional distribution of human capital. Our analysis confirms the importance of human capital and research facilities in stimulating regional patent output. Our results document the importance of agglomeration and spatial factors in influencing creativity: patent activity is increased in larger and more dense labour markets and in regions in which a larger fraction of the labour force is employed in medium-sized firms. Our results also indicate that creativity is greater in labour markets with more diverse employment bases and in those which contain a larger share of national employment in certain industries, thus confirming the importance of urbanisation and localisation economies in stimulating creativity. Our quantitative results suggest that the urbanisation of Sweden during the 1990s had an important effect upon the aggregate level of patent activity in the country, leading to increases of up to 15 percent in aggregate patents.
\end{abstract}

JEL classification: O31, N34, R11

Key words: Commercial patents, localisation economies, urbanisation economies, agglomeration 


\section{Introduction}

It is widely reported that agglomerations of economic activity in space lead to increased productivity and enhanced economic output. Early evidence, based on production functions, established that output per worker is higher in urban regions that are larger and denser (e.g., Shefer 1973). A variety of explanations are offered for these regularities, ranging from better functioning labour markets in larger, denser environments, to Marshallian external economies of scale in production, to the increased possibilities for the division of labour in large conurbations (see Quigley 1998 for a review).

In this article we trace the relationship between the size, density, scale, and specialisation of economic regions and "creativity" - the production of new knowledge in those regions. We measure creativity by the award of patents for commercial innovations in Sweden. We measure patents for a panel of 100 Labour Market Areas in Sweden covering the entire country over an eight-year period. We also measure the economic characteristics of these labour market areas, including the industrial composition of the region, the human capital of the workforce, and the intensity of research and development activity in the region.

We pay special attention to the spatial character of each region - the density of economic activity, the scale of each region, and the extent of industrial concentration or diversity of each of these labour market areas. We find that the density and scale of regional activity matter greatly in the incidence of creativity, so measured. We also find that there are large returns, as measured by patents, to the diversity of regional economic activity. At the same time, we find that there are returns to the concentration of specialised industries in a small number of labour market areas.

Section 2 below provides a selective review of the literature on the determinants of patent activity. We describe the data and our general hypotheses in Sect. 3. We report our principal results and consider their robustness in Sect. 4. Conclusions follow.

\section{A brief literature review}

Alfred Marshall $(1898,1920)$ first drew attention to the economic effects of agglomeration and to scale economics external to an individual firm but internal to an industrial district or cluster. He argued that the co-location of firms increased output and the productivity of inputs. Externalities flowing from inputs of human capital in a spatial context experienced a scientific revival with the endogenous growth models of Romer (1986, 1990), Lucas (1988), and Grossman and Helpman (1991). Griliches $(1979,1998)$, Anselin et al. (1997), and Acs (2002) have modelled this effect in a simple production function at the regional level using local industrial and university research as inputs. Each of these studies reported a significant and positive effect of research, in particular university research, on output; this is generally interpreted as evidence of knowledge transfers arising from or mediated by the university. 
As Marshall and later Krugman (1991), Feldman (1994), Jaffe et al. (1993), Audretsch and Feldman (1996), and others have emphasised, space itself forms a barrier to the diffusion of knowledge. Daily face-to-face contact may be quite important in the diffusion of results from scientific research and development (R\&D). Commercial developers can therefore benefit by locating close to universities and other centres of basic research. However, geographic proximity to other firms in the same industry may be of even greater importance in stimulating applied research and innovations that improve practice.

Work by Glaeser et al. (1992) and by Henderson et al. (1995) documents the link between spatial concentration of economic activity, economic growth, and productivity in U.S. cities. Glaeser et al. conclude that economic diversity (fostering "Jacobs-type" externalities) is more important in affecting economic growth. Henderson et al. distinguish between the growth of high-tech industries (for which Jacobs-type externalities are important) and capital goods industries (for which economic specialisation is more important).

Varga (1998) investigated the importance of agglomeration in the production of new knowledge in the U.S. He measured research output using more than 4,000 product innovations recorded in 1982. As inputs, he measured annual expenditures for research in American universities as well as the number of employees in laboratories and research institutes within private companies. He then related the number of product innovations to annual expenditures for university research, finding that important returns to scale and scope exist. Varga concluded that there is a critical mass relating scale and scope to the output of innovative activity and to the density and size of a region.

Several analyses of the importance of firm location and knowledge infrastructure have been undertaken in Sweden. Lundquist (2001) analysed cross sectional data for Sweden for 1996, finding little or no statistical relationship between the locations of start-up firms and the locations of colleges and universities. His qualitative conclusions are quite similar to those of Florax (1992), namely that proximity to a college or university is not a significant factor in explaining regional variations in the incidence and location of new start-up companies. Our own work (Andersson et al. 2004) questions these conclusions, at least for Sweden.

During the last two decades, data on patents have been relied upon in increasingly investigating the production of knowledge (Griliches 1984). In his 1990 survey paper, Griliches evaluates patent statistics as economic indicators, emphasising that a patent represents "a minimal quantum of invention that has passed both the scrutiny of the patent office as to its novelty and the test of the investment of effort and resources by the inventor (p. 1669)." He emphasises that patents comprise only a subset of all inventions, since a great many valuable inventions are not patented, while, Trajtenberg (1990) and Jaffe and Trajtenberg (2002) caution that citation-weighted patent counts are a better measure of the value of patents than unweighted counts of patents.

Using patent counts, Acs et al. (2002) found that both university research and private R\&D exerted substantial effects on innovative activity in U.S. metropolitan areas, with a clear dominance of private $R \& D$ over university research. 
Fischer and Varga (2003) also analysed patent counts as proxies for the output of regional knowledge production, while university research and corporate R\&D investment represent the input side. They used spatial econometric methods to test for spatial effects - spillovers - in Austria on a rather fine spatial scale, more than 90 small political districts. They confirmed the presence of local geographic spillovers, but they also found that these spillovers attenuate quickly with distance.

Jaffe (1986) investigated the link between patents and the R\&D activities of firms. His research suggests that knowledge transfers occur more easily among companies in regions with a high output of patents. Companies performing research in areas where a considerable amount of research is carried out by other companies also appear to generate more patents per dollar spent on R\&D than companies located in areas where relatively little research is conducted by other companies. Thus, clusters of research companies facilitate the diffusion of new knowledge. Jaffe (1989) analysed time series data on corporate patents for U.S. states, corporate R\&D, and university research, investigating spillovers from academic research. He found a significant effect of university research on corporate patents. Jaffe's research also suggested that university research may have an indirect effect on local innovation by inducing R\&D spending by private firms. ${ }^{1}$

The research reported in this article is perhaps closest to work done by Feldman and Audretsch (1999) and work currently underway by Jerry Carlino and his associates (2004) at the Federal Reserve Bank of Philadelphia. Carlino et al. relate patent intensity (i.e., patents per capita) in U.S. metropolitan areas (MSAs) to a variety of aggregate characteristics - size, density and specialisation. Their model is based on a cross section of 280 metropolitan areas, observing initial metropolitan conditions in 1990 and patent activity aggregated over the subsequent decade. As noted below, our analysis is based on an eight-year panel of Swedish labour market areas in which we observe patent activity and metropolitan characteristics. Our statistical models vary slightly from those employed by Carlino et al. and our measurements of metropolitan characteristics are somewhat more elaborate.

\section{Data and hypotheses}

Our principal dependent variable is based upon patents registered to the Swedish Patents and Registration Board or the European Patent Office during the period 1994-2001. Data on Swedish patent awards publicly available include the home address of the inventor(s) of record. We allocate each invention to the labour market area in which the inventor resides. ${ }^{2}$ Figure 1 reports the number of patents and patents per capita reported in these data. During the 1994-2001 period, about

\footnotetext{
${ }^{1}$ Jaffe points out that he would have preferred to carry out his regional analysis on a finer spatial scale using economically more meaningful units than U.S. states.

${ }^{2}$ In the case of multiple inventors, we pro-rate each invention to the labour market in which the inventors reside.
} 


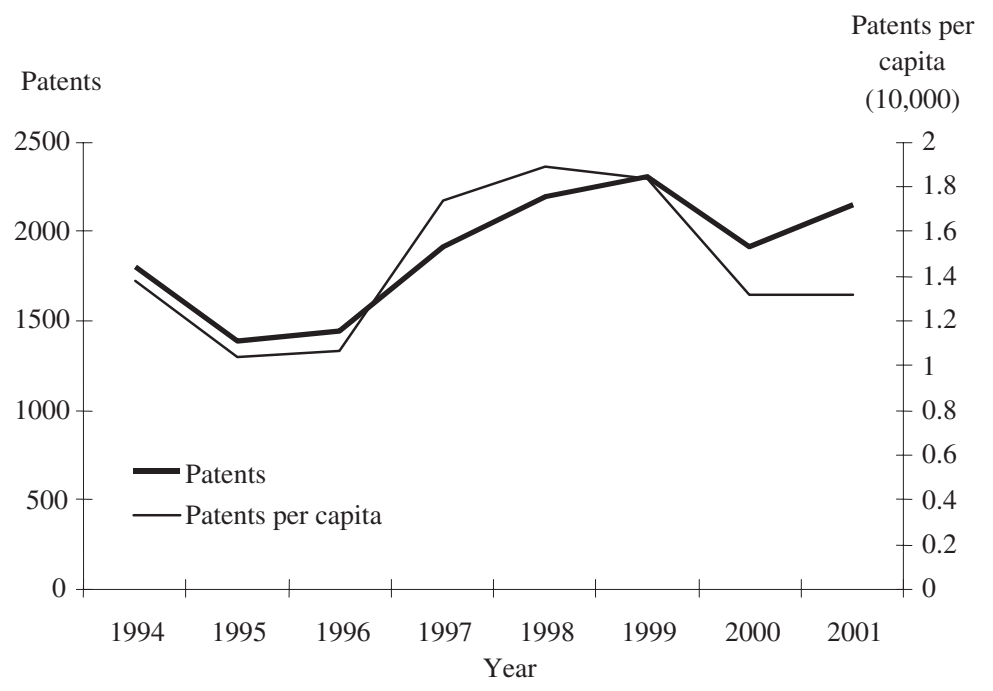

Fig. 1. Aggregate patents and patents per capita, 1994-2001

16,500 commercial patents were approved; annual patents ranged between 1,200 and 2,200 on a slightly upward trajectory. On average, patents ranged between about 1 and 1.8 per 10,000 of population. Per capita patents were largest in $1997-1998 .^{3}$

Labour market areas are defined by the Swedish Labour Ministry on the basis of commuting patterns, using methods analogous to those used to define MSAs in the United States. Most, but not all, of Sweden's 100 labour market areas contain a central city and a number of surrounding jurisdictions. Figure 2 indicates the geography of these labour market areas; they vary substantially in size and in the intensity of patent activity. The average number of patents and the average number of patents per capita is largest in the three largest metropolitan areas, Stockholm, Gothenberg and Malmö. Almost half of Swedish patents originated in these three labour markets. There is, however, some patent activity in each of the labour market areas, including those in the far north of the country.

Figure 3 reports the distribution of patents per capita, in six categories averaged across the eight years. In the top decile of the distribution of patents by labour market area, patents averaged about 4 per 10,000 in population. In the next 15 percent of the distribution, patents averaged about 2 per 10,000. In the bottom decile, patents averaged about 0.5 per 10,000. Clearly, there is considerable variation in patent awards over time and across labour markets.

\footnotetext{
${ }^{3}$ In comparison, Carlino et al. (2004) report 2.1 patents per 10,000 for the U.S. during 1990-1999.
} 

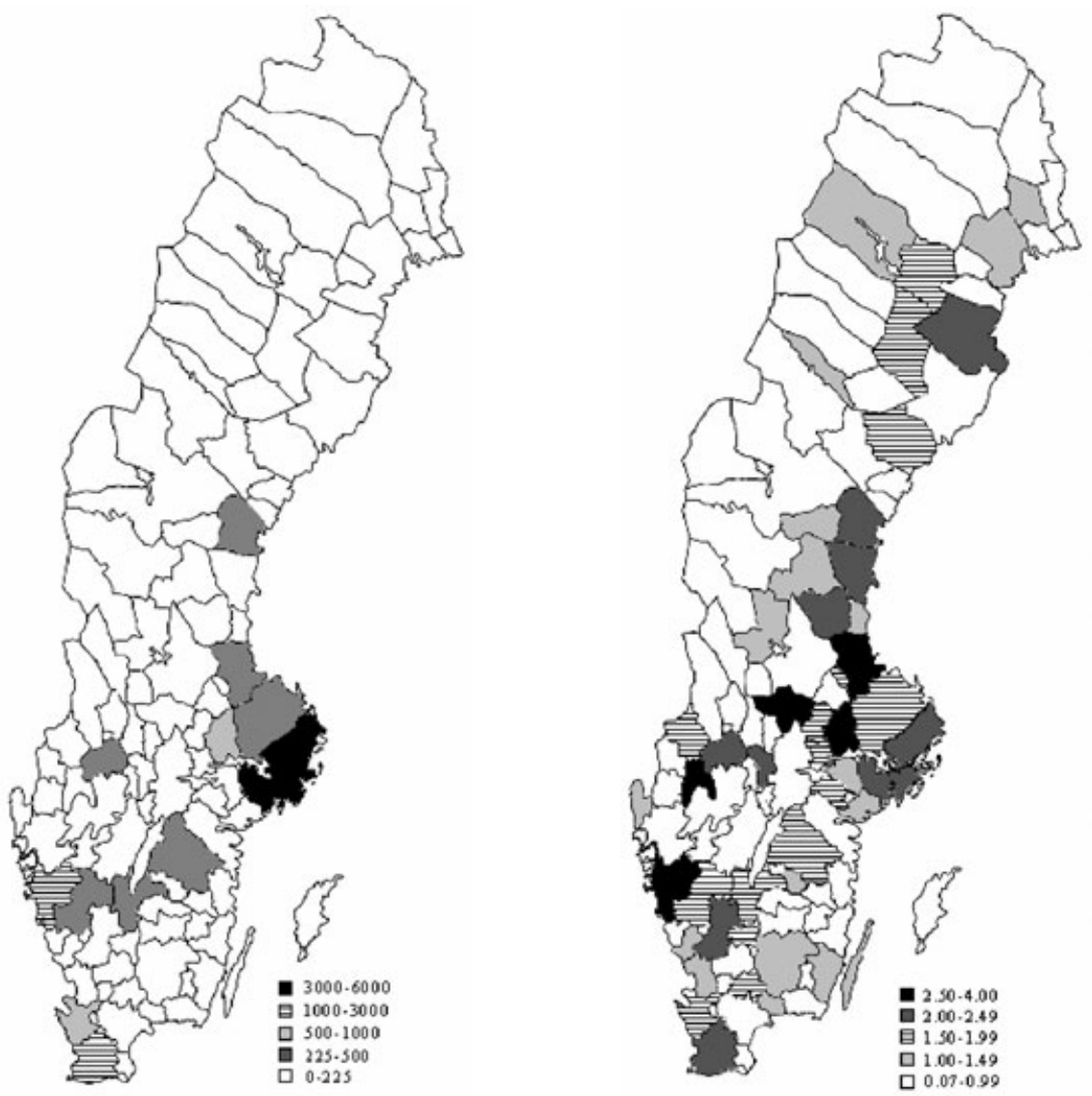

Fig. 2. The spatial distribution of patents

We investigate the systematic relationship between the level of innovative activity in these regions and four broad classes of determinants: human capital; industrial structure; agglomeration; diversity. The link between human capital and patents presents the simplest and most straightforward hypothesis. Labour forces with more highly educated workforces are more likely to have higher levels of innovative activity and creativity, hence higher patent awards. The link between industrial structure and patents is less obvious. Traditional models of industrial organisation (e.g., Schumpeter 1934) emphasised the importance of firm size and scale in fostering innovative activity. Larger, more differentiated firms may structure divisions to pursue innovations and patents. More recent scholarship (Porter 1998) emphasises the innovative potential of smaller, more nimble and less differentiated firms. 


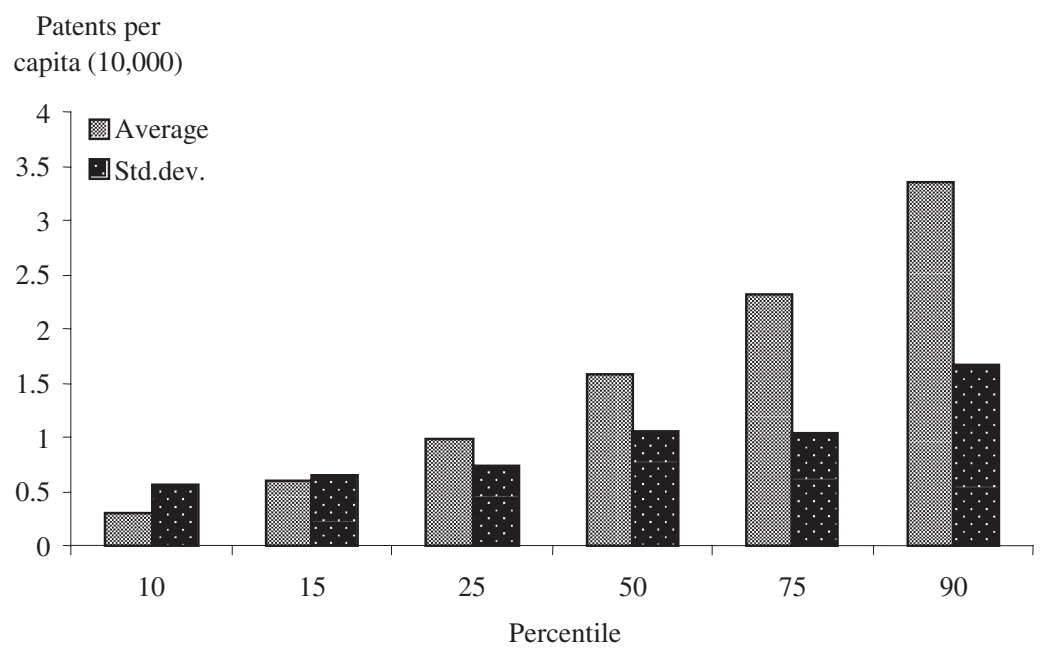

Fig. 3. Average patents per capita in six different classes

The link of innovation to agglomeration is through local externalities across firms, increasing the likelihood of adapting advances in one firm to other firms and industries in close proximity (Glaeser et al. 1992). The hypothesised linkage between economic diversity and innovation follows from Jane Jacobs' (1961, 1969) verbal insights about economic growth and urban heterogeneity, as well as more recent work quantifying the linkage between economic diversity and economic growth (Wagner and Deller 1998).

We assembled data to investigate these broad hypotheses across time and space using these data on innovations in Swedish labour market areas. For each labour market area, we assembled annual information on the local labour force and industrial structure. Information on labour force characteristics includes the number of employees and the distribution of their educational attainments. Information on the industrial structure includes the number of employees by industry as well as the size distribution of establishments. These labour market area data are available annually from Statistics Sweden.

We also assembled information on the research capacity and R\&D facilities located in each of the labour market areas. ${ }^{4}$ Estimates of the number of full time researchers in private firms are available annually at the county level. ${ }^{5}$ We estimated the distribution of researchers at the level of the labour market area by distributing the county totals to constituent labour markets in proportion to the number of workers with doctoral degrees in each labour market. The number of

\footnotetext{
${ }^{4}$ Labour market areas containing private R\&D facilities operated by the 20 largest firms in Sweden were identified by telephone survey.

5 There are 26 counties in Sweden, amalgams of one or more labour market areas.
} 


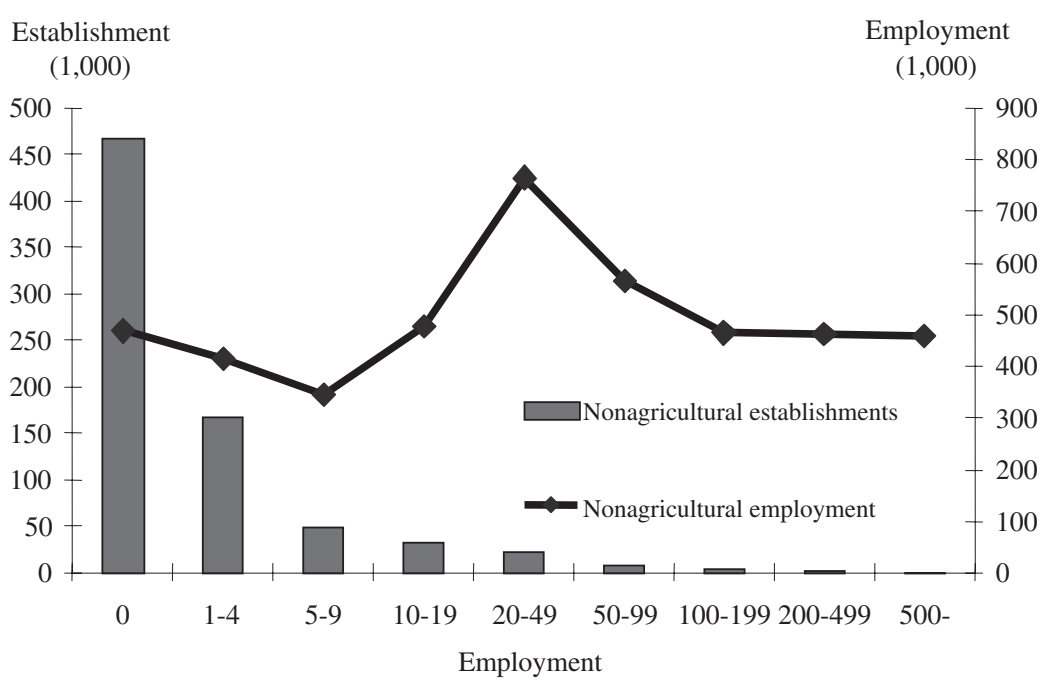

Fig. 4. Number of establishments and employment by size of establishment, 2001

technical researchers in the public sector (mainly at universities) is also available at the level of the labour market area.

Figure 4 reports the size distribution of non-agricultural establishments in 2001. More than 450,000 establishments (out of 751,000 non-agricultural establishments in Sweden) report no employees other than the owner. Another 150,000 establishments had fewer than five workers including the owner. Despite the large number of small establishments, they employ only a small proportion of Swedish workers. More than 17 percent of non-agricultural workers were employed in establishments of 20-49 workers, and 44 percent of the non-agricultural workforce was employed in establishments of more than 50 workers.

Figure 5 presents the rank size relationship for patents; it presents a graph of the logarithm of patent production as a function of the rank of each labour market in terms of employment. The exponential increase in patents with population rank is clearly evident in the raw data.

Table 1 summarises the descriptive data assembled for each labour market area for each year. We measure total employment and the fraction of employees working in small (fewer than 10 employees) and large establishments (with more than 100 employees). We measure the average number of establishments per employee and also the number of establishments per employee in manufacturing. We measure the proportion of total employment in each labour market area and each year who are working in the manufacturing sector and, within manufacturing, the proportion working in four large components: paper, chemicals (including pharmaceuticals), electronics, and transport.

We measure the human capital of the labour force by the proportion of employees with post secondary education and the average years of education of the labour force. We also measure the fraction of the workforce with advanced 


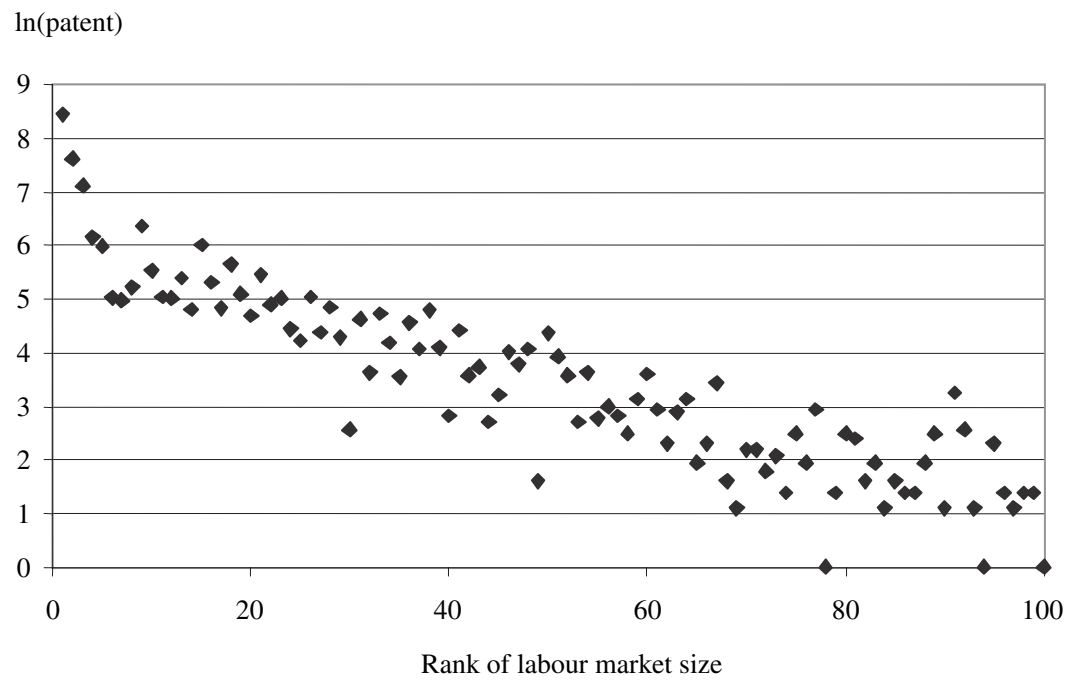

Fig. 5. Total number of patents by rank of labour market size, 1994

degrees, masters and doctoral degrees, as well as the fraction of workers engaged full time in R\&D activities. For each labour market area, we also record the existence of an R\&D facility operated by a large private company and a university R\&D facility.

We measure the spatial structure of three labour markets in each year by a series of variables reflecting density, heterogeneity and concentration. We measure the density of employment (e.g., employees per square kilometer), of establishments, of small establishments (with fewer than 10 employees), large establishments (with more than 100 employees) and research workers in each labour market area in each year. We also compute these same density measures for the most dense political jurisdiction within each labour market area.

We measure the diversity of employment in each labour market by the Hirfindahl Index of concentration for 24 business sectors, and similarly for 14 components of the manufacturing sector. We also compute the concentration of national industry in each labour market area separately for the paper, chemical (including pharmaceuticals), electronics (including power and electricity), and transport sectors. For each labour market, we compute the share of employment in each industry relative to the share of total employment in that labour market.

Table 2 reports the mean values of these variables separately for six groups of labour market areas in 2000. These six categories correspond to the percentiles reported in Fig. 3, that is, the 10th, 25th, 50th, and 75th, and 90th percentiles of the distribution of patents by labour market area during 1994-2001. The number of patents in 2000 averaged about 0.6 in each of the labour markets in the bottom decile in 2000, and averaged 112.6 in each of the labour markets in the top decile.

There is a generally increasing share of employment in manufacturing in those labour market areas with more patent activity, and increasing shares of 


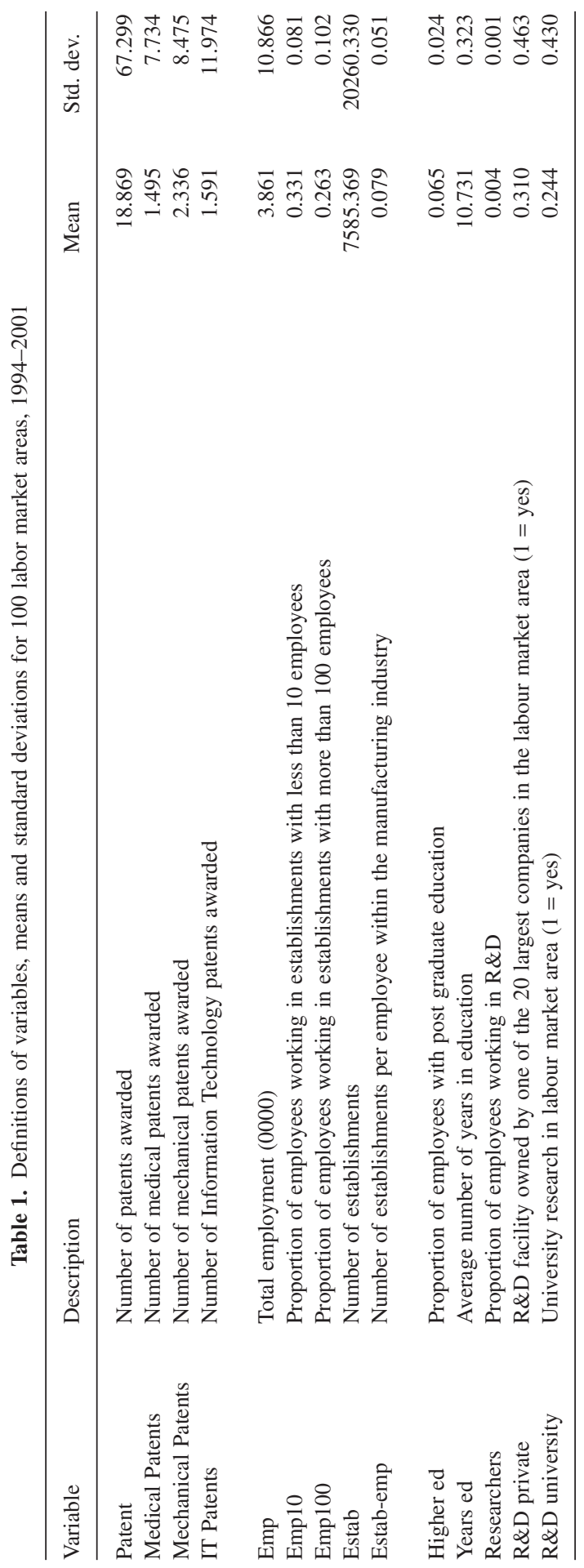




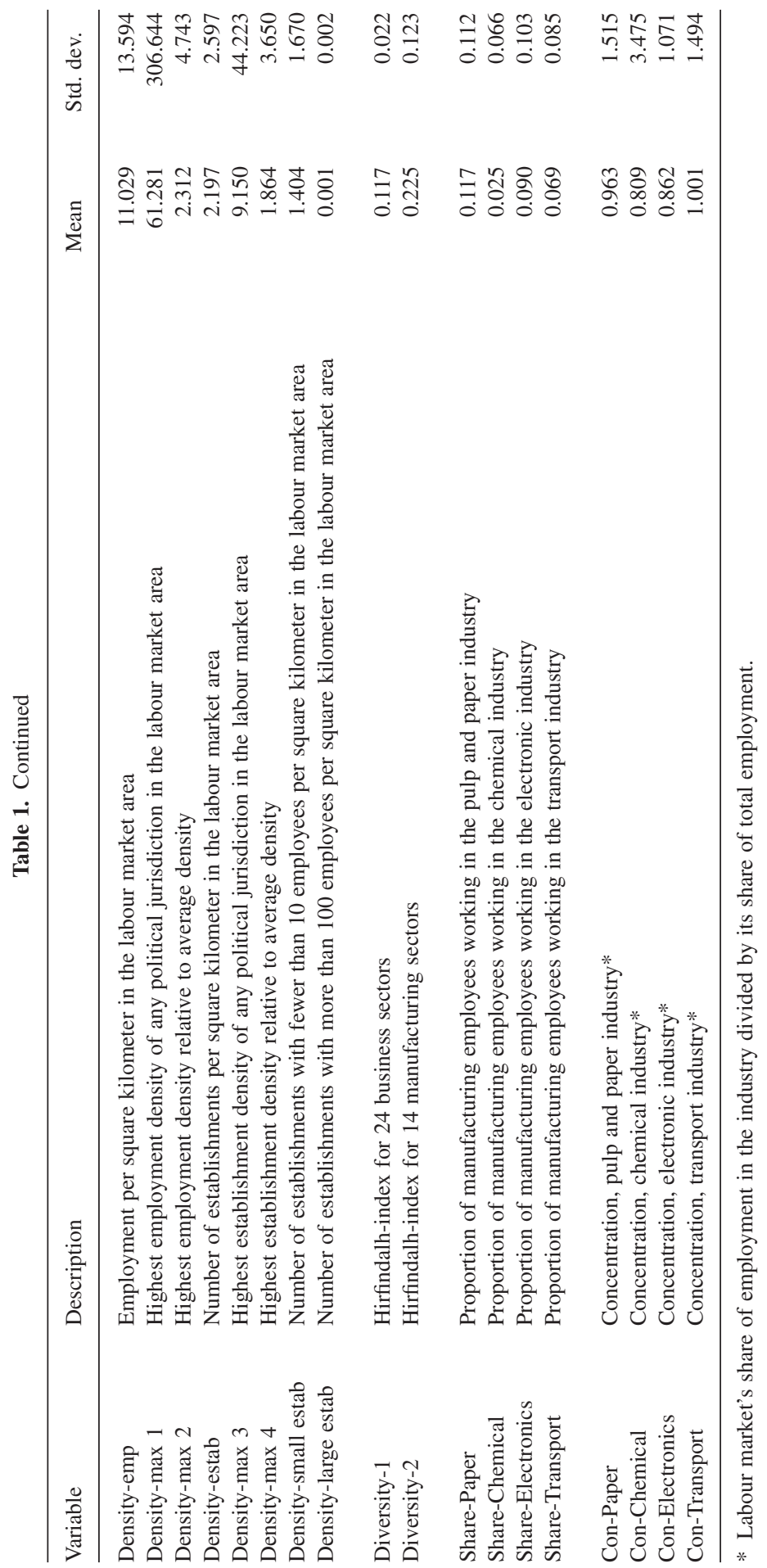


Table 2. Characteristics of labour market areas by percentile in the number of patents awarded, 2000

\begin{tabular}{|c|c|c|c|c|c|c|}
\hline \multirow[t]{2}{*}{ Variable } & \multicolumn{6}{|c|}{ Percentile in Patent Awards } \\
\hline & 10 & 15 & 25 & 50 & 75 & 90 \\
\hline Number of Patents Awarded & 6 & 17 & 154 & 227 & 380 & 1126 \\
\hline Medical Patents & 1 & 0 & 7 & 9 & 27 & 130 \\
\hline Mechanical Patents & 0 & 2 & 17 & 24 & 37 & 108 \\
\hline IT Patents & 0 & 1 & 5 & 3 & 43 & 161 \\
\hline \multicolumn{7}{|l|}{ A. Industrial composition } \\
\hline Share-Paper & 0.092 & 0.142 & 0.111 & 0.089 & 0.099 & 0.157 \\
\hline Share-Chemical & 0.013 & 0.010 & 0.018 & 0.024 & 0.029 & 0.070 \\
\hline Share-Electronics & 0.113 & 0.113 & 0.089 & 0.088 & 0.093 & 0.182 \\
\hline Share-Transport & 0.069 & 0.024 & 0.084 & 0.104 & 0.055 & 0.060 \\
\hline \multicolumn{7}{|l|}{ B. Human capital } \\
\hline Higher Ed & 0.067 & 0.073 & 0.087 & 0.079 & 0.087 & 0.105 \\
\hline Doctors & 0.001 & 0.001 & 0.002 & 0.002 & 0.003 & 0.004 \\
\hline Masters & 0.066 & 0.072 & 0.085 & 0.077 & 0.085 & 0.101 \\
\hline Years Ed & 10.769 & 10.879 & 11.004 & 10.949 & 11.022 & 11.192 \\
\hline Researchers & 0.002 & 0.002 & 0.003 & 0.004 & 0.005 & 0.010 \\
\hline Private R\&D facilities & 0.100 & 0.067 & 0.200 & 0.360 & 0.533 & 0.700 \\
\hline R\&D facility & 0.062 & 0.083 & 0.310 & 0.270 & 0.200 & 0.500 \\
\hline \multicolumn{7}{|l|}{ C. Agglomeration } \\
\hline Density-emp & 4.11 & 3.12 & 10.21 & 11.04 & 15.32 & 28.39 \\
\hline Density-max-1 & 5.59 & 4.06 & 19.44 & 22.78 & 87.22 & 406.60 \\
\hline Density-establ & 1.33 & 0.91 & 2.36 & 2.54 & 3.35 & 5.64 \\
\hline Density-max-3 & 1.47 & 0.99 & 3.64 & 4.00 & 13.85 & 64.36 \\
\hline Con-Paper & 1.457 & 0.354 & 1.999 & 0.870 & 0.648 & 0.589 \\
\hline Con-Chemical & 0.206 & 0.159 & 0.478 & 0.675 & 0.919 & 3.156 \\
\hline Con-Electronics & 0.861 & 0.909 & 0.832 & 0.919 & 0.918 & 1.955 \\
\hline Con-Transport & 0.757 & 0.352 & 1.049 & 1.558 & 0.972 & 0.682 \\
\hline Diversity-1 & 0.125 & 0.118 & 0.114 & 0.108 & 0.118 & 0.121 \\
\hline Diversity-2 & 0.272 & 0.243 & 0.199 & 0.204 & 0.218 & 0.247 \\
\hline \multicolumn{7}{|l|}{ D. Scope } \\
\hline Estab & 22629 & 35558 & 165980 & 155948 & 162852 & 352088 \\
\hline Emp & 72525 & 111535 & 714081 & 666674 & 729982 & 1757073 \\
\hline Emp10 & 0.39 & 0.43 & 0.36 & 0.35 & 0.32 & 0.29 \\
\hline Emp100 & 0.19 & 0.17 & 0.24 & 0.25 & 0.28 & 0.32 \\
\hline Estab-emp & 0.11 & 0.14 & 0.08 & 0.08 & 0.07 & 0.06 \\
\hline
\end{tabular}

employment in paper, chemicals, and electronics, at least at the highest decile. The fraction of workers with post secondary schooling is generally higher in labour market areas with more patent activity. Patent activity is increasing monotonically with the fraction of workers with masters' degrees, doctoral degrees, and with the fraction of employees working in research jobs.

There is a monotonic relationship between the density of employees and the density of establishments in labour market areas and the incidence of patent 
activity. Likewise, there is a monotonic relationship between the density of employees and establishments in the densest political jurisdiction of a labour market area and patent production. There is no simple relationship between the measures of diversity and establishments per worker and patent activity.

\section{Statistical models}

Of course, many of the measures reported in Table 2 are themselves highly correlated, and a simple univariate comparison may be highly misleading. We can relate patent counts, $\eta_{i t}$, by labour market $i$ and year, $t$, to these factors by estimating a count model.

$$
\begin{gathered}
\operatorname{prob}\left(\eta_{i t}=y_{i t}\right)=\frac{e^{\mu_{i t} \lambda_{i t}}\left(\mu_{i t} \lambda_{i t}\right)^{y_{i t}}}{\mathrm{y}_{i t} !} \\
\log \lambda_{i t}+\log \mu_{i t}=X \beta,
\end{gathered}
$$

where the probability that the count $\eta_{i t}$ is equal to $\mathrm{y}_{i t}$ is expressed in Eq. (1). The vector $X$ represents characteristics of labour market $i$ at time $t$, and $\beta$ is a vector of parameters. If $\mu_{i t}=1$, the mean and the variance of the count distribution are equal, and Eq. (1) is a straightforward Poisson model. If the mean and variance of the count distribution are unequal, parameters of the model may be represented as a straightforward negative binomial count model. ${ }^{6}$

Table 3 reports the coefficients of the count model, estimated by maximum likelihood methods. Since $\alpha$, the over-dispersion parameter, is significantly different from zero, the preferred model is the negative binomial. Model 1, the "Base Model," includes total employment and employment density, as well as measures of heterogeneity of employment, the education of the workforce, the distribution of employment by industry and the concentration of national industry in each labour market area.

The aggregate employment of each labour market area is clearly important in affecting patents. Patent activity is greater in regions where there is more economic activity. Creativity, at least as measured by patents, is larger where a larger fraction of the workforce has completed post secondary education. Patents are also larger in regions where a larger fraction of the workforce is employed in research jobs.

Model 2 experiments by considering both measures of workforce diversity. Creativity is clearly larger where there is a greater diversity of employment within manufacturing. Patent activity is less when a larger fraction of the workforce is employed in very small firms (fewer than 10 employees) or in very large establishments (over 100 employees).

\footnotetext{
${ }^{6}$ This follows, for example, if we assume that $\mu_{i t}$ follows a gamma distribution, $\mu_{i t} \sim$ Gamma $(1 / \alpha, \alpha)$. If $\alpha=0$, the model is Poisson. If $\alpha>0$, the model is negative binomial.
} 


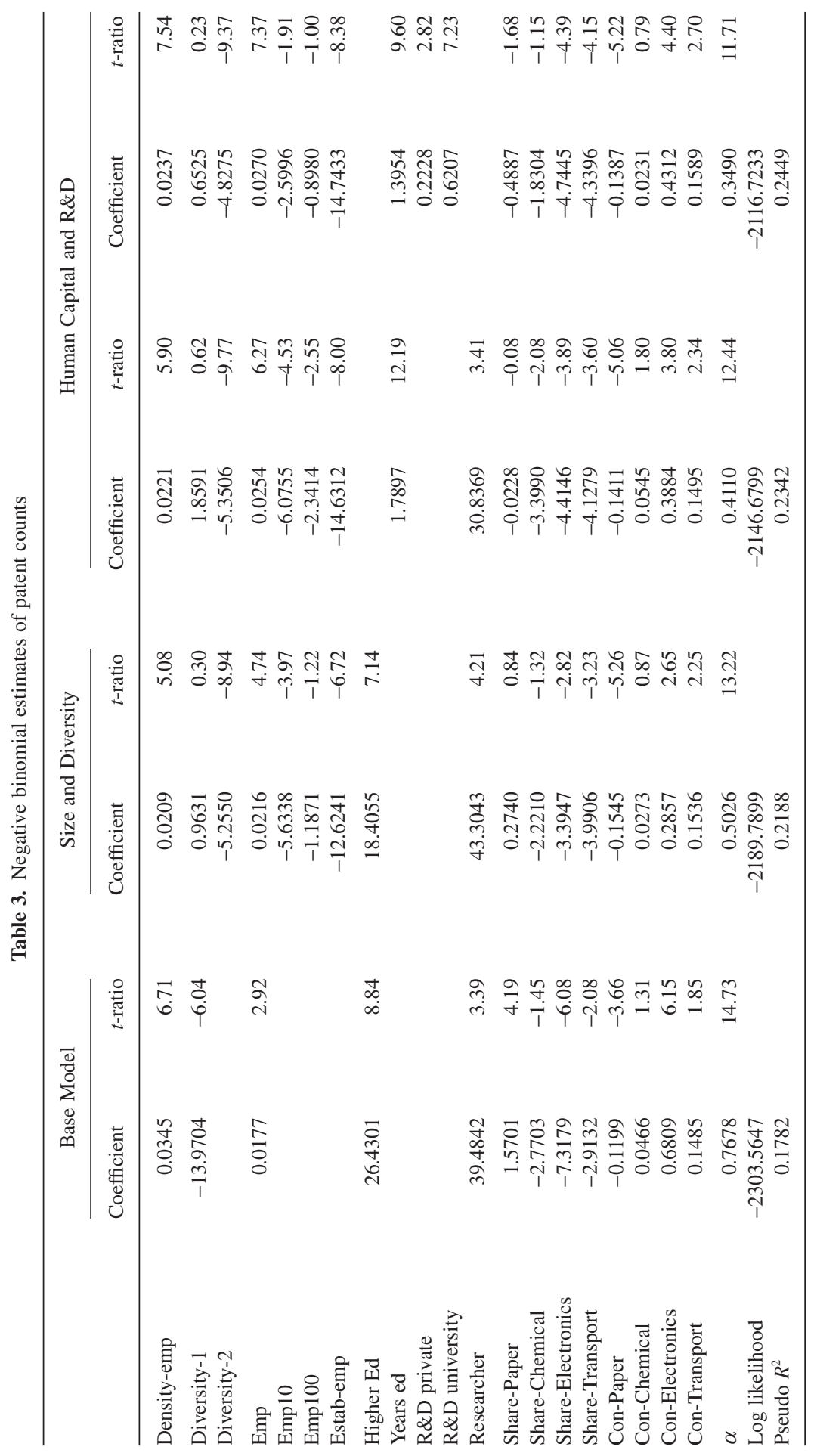


Model 3 uses the average years of education of the workforce as the measure of human capital. Model 4 disaggregates the human capital measures into the fraction with a masters degree and the fraction with doctoral degrees. These models are indistinguishable from the other measures of human capital.

Table 4 explores the relationship between the spatial structure of these labour market areas and their patent intensity. The first two models report the results of different models relating the density of employment to patent output. Ceteris paribus, it is clear that labour market areas that are denser - in terms of employees per square kilometer - have higher outputs of patents. Holding density constant, however, it also seems clear (from models 1 and 2) that patent output is larger in labour market areas that are more uniform in the density of employees. From Model 3, it is also clear that, holding average density itself constant, the density of very large establishments is negatively related to patent output. When the existence of private sector or university R\&D facilities is accounted for, the importance of density is reduced, but certainly not eliminated.

The last three models in Table 4 report analogous results when density is measured by establishments per square kilometer. Patent output is higher when the density of establishments is higher. Holding establishment density constant, patent activity is higher when that density is more uniformly distributed within the labour market area.

In all the results reported in Tables 3 and 4, patent activity in a labour market area is greater when a larger share of national employment in chemicals, electronics, or transport is concentrated in that labour market area. Patent activity is less in labour market areas containing a large fraction of national employment in pulp and paper. It is also consistently true that patent activity is greater when the share of aggregate employment in the local labour market area in these manufacturing sectors is smaller.

Table 5 explores the links between spatial factors and creativity for three specific fields - medical patents (1,196 during 1994-2001), mechanical $(1,869)$ and information technology $(1,273)$. The table reports the results of our preferred specification in predicting patent counts in these industries and scientific specialties for the panel of labour markets during the 1994-2001 period. With no exceptions, creativity in medical and mechanical advances follows the pattern reported in Tables 3 and 4 for all innovations. For the IT sector, however, the results are quite different. Patent counts in IT are unrelated to the employment base of the labour market area; they vary with the density of the largest community, not the labour market area as a whole. Patent activity in IT also varies positively with the density of large establishments. The findings from the IT sector are worthy of further exploration.

Finally, it is possible that our statistical results are affected by the dominance of the Stockholm labour market area. As in other smaller countries, the capital region has a disproportionate share of population and economic activity. To test the robustness of our results, we have re-estimated our preferred models eliminating the Stockholm labour market area from the panel. We also re-estimated the negative binomial count model including a fixed effect for the Stockholm region. None of the principal empirical results are affected by these modifications. Appendix Table A1 reports these models. 


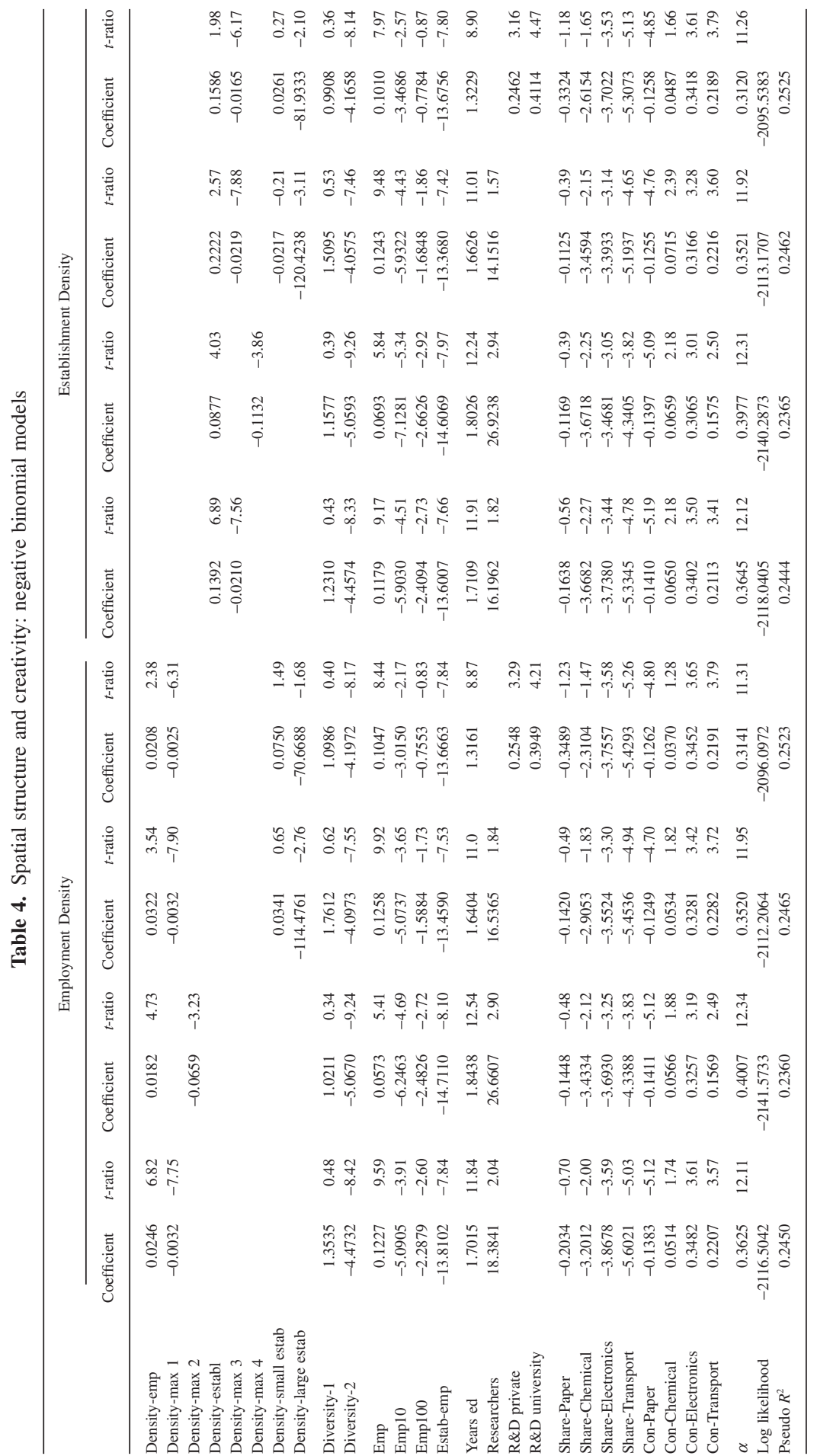




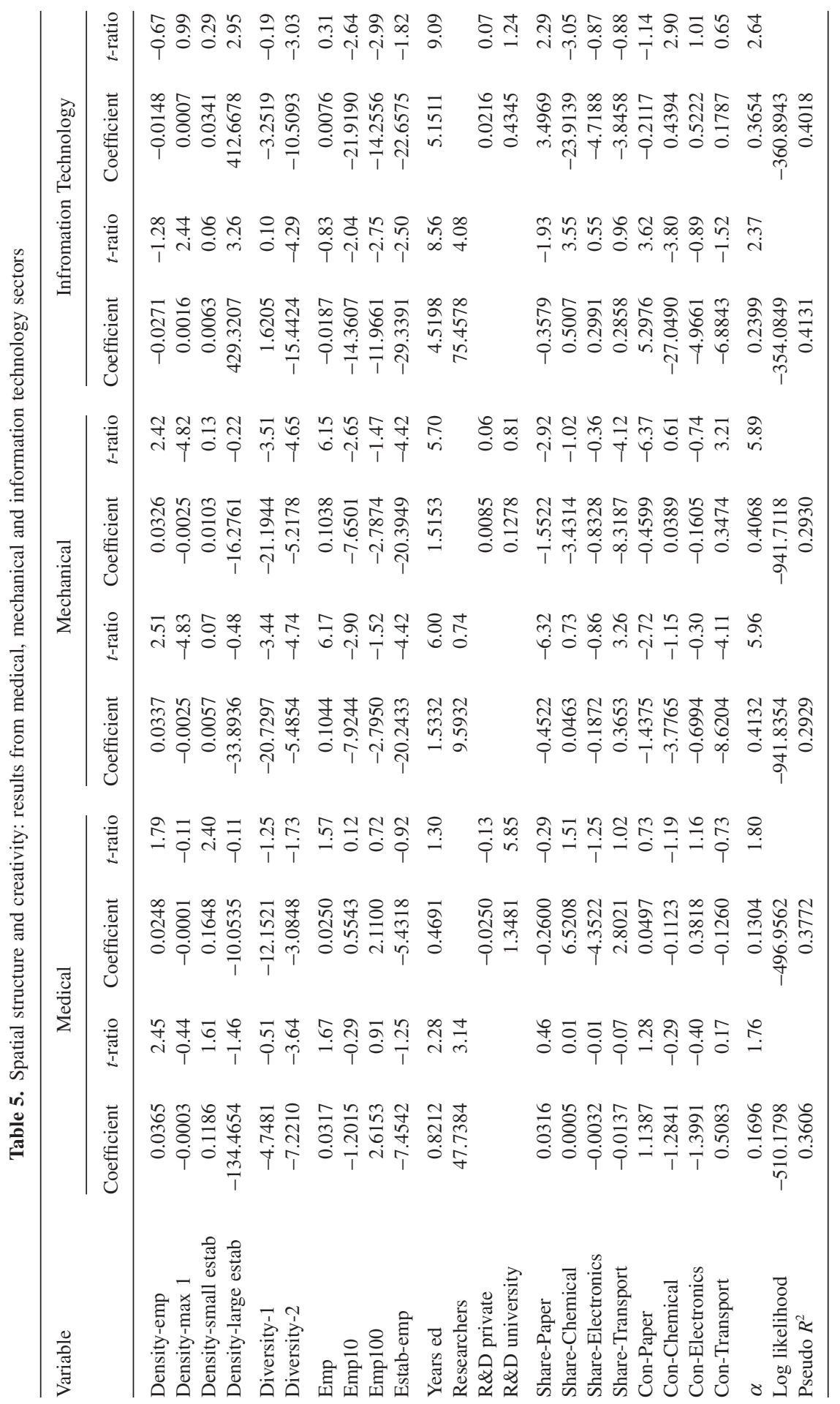




\section{Conclusion}

This article presents an economic model to explain the spatial distribution of creativity as measured by commercial patents obtained for new knowledge created during the 1994-2001 period. Our model investigates the importance of agglomeration and spatial factors in affecting patent activity. We find that patents are responsive to the spatial distribution of workers at different levels of education and the distribution of private and university R\&D facilities.

We also find, however, that the level of innovation is sensitive to the density of economic activity of differing kinds, including the density of employment and the density of large and small establishments. Our quantitative results suggest that density and urbanisation really do matter in the creation of new knowledge. For example, the level of innovation in each region can be estimated under the counterfactual of no increases in urbanisation in Sweden during 1994-2001. To do this, we assume that average employment change in Sweden during 1994-2001 is applied proportionately to all the labour markets instead of the actual urbanisation process that has further concentrated economic activity in larger, denser regions. Using the coefficients in Table A1, we estimated that the net effect of this spatial rearrangement of employment would have a decreased patent activity by 1.9 percent per year or by about 15 percent over the period.

This is a substantial change in aggregate innovative activity. We also found results, which broadly support Jane Jacobs' hypothesis that diversity "matters" for creativity, especially within manufacturing industries. Innovation may be the mechanism responsible for the linkage between economic growth and diversity reported for U.S. cities (Glaeser et al. 1992). We also find support for the importance of concentration within the electronics (power and generating) industry and the transport sector as suggested by Henderson et al. (1995) for U.S. capital goods industries.

Finally, our results confirm the well-known importance of human capital for the innovation creativity. Thus the presence of university research increases the number of patents awarded in a labour market by [exp $(0.39)-1]$ or by about $0.5 \%$ in any year, and the presence of R\&D facilities established by the private sector increases the number of patents by about 0.3 percent.

\section{References}

Acs Z (2002) Innovation and the growth of cities. Edward Elgar, Cheltenham, UK and Northampton, MA

Acs Z, Anselin L, Varga A (2002) Patents and innovation counts as measures of regional production of new knowledge. Research Policy 31: 1069-1085

Andersson R, Quigley J, Wilhelmsson M (2004) University decentralization as regional policy: The Swedish Experiment. Journal of Economic Geography 4: 371-388

Anselin L, Varga A, Acs Z (1997) Local geographic spillovers between university research and high technology innovations. Journal of Urban Economics 42: 422-448

Audretsch D, Feldman M (1999) Innovation in Cities: Science-based diversity specialization and localized Competition. European Economic Review 43: 409-429.

Audretsch D, Feldman M (1996) R\&D Spillovers and the geography of innovation and production. American Economic Review 86: 630-640 
Carlino J, Satyajit C, Hunt R (2004) Matching and learning in cities: Evidence from patent data. Working Paper 04-16. Federal Reserve Bank of Philadelphia

Feldman M (1994) The geography of innovation. Kluwer Academic Publishers, Boston, MA

Fischer M, Varga A (2003) Spatial knowledge spillovers and university research: Evidence from Austria. The Annals of Regional Science 37: 303-322

Florax R (1992) The university: A regional booster? Aldershot, Avebury

Glaeser EL, Kallal HD, Scheinkman JA, Shleifer A (1992) Growth in cities. Journal of Political Economy 100(61): 1126-1152

Griliches Z (1979) Issues in assessing the contribution of r\&d to productivity growth. Bell Journal of Economics, Spring, 10: 92-116

Griliches Z (ed) (1984) $R \& D$, patents and productivity. University of Chicago Press, Chicago

Griliches, Z (1990) Patent statistics as economic indicators: A survey. Journal of Economic Literature, Vol. VIII: 1661-1707.

Griliches Z (1998) $R \& D$ and productivity. The University of Chicago Press, Chicago

Grossman GM, Helpman E (1991) Innovation and growth in the global economy. The MIT Press Cambridge, MA

Henderson V, Kuncoro A, Turner M (1995) Industrial development in cities. Journal of Political Economy 103(5): 1067-1090

Jacobs J (1961) The death and life of great American cities. Random House, New York

Jacobs J (1969) The economy of cities. Random House, New York

Jaffe A (1986) Technological opportunity and spillovers of r\&d: evidence from firms patents, profits and market value. American Economic Review 6: 984-1001

Jaffe A (1989) Real effects of academic research. American Economic Review 79: 957-970

Jaffe A, Trajtenberg M, Henderson R (1993) Geographic localization of knowledge spillovers an evidenced by patent citations. Quarterly Journal of Economics 63: 577-598

Jaffe A, Trajtenberg M (ed) (2002) Patents, citations and innovations: A window on the knowledge economy. The MIT Press, Cambridge, Massachusetts, London, England

Krugman P (1991) Increasing returns and economic geography. Journal of Political Economy, 483-499

Lucas R (1988) On the mechanics of economic development. Journal of Monetary Economics, July, 22(1): $3-42$

Lundquist K (2001) “Universities and Firms," Uddevalla Symposium 2000, Research Reports 01:2, Papers presented at the Uddevalla Symposium 2000, 15-17 June, Trollhättan, Sweden.

Marshall A (1890, 1920) Principles of economics

Porter ME (1998) The competitive advantages of nations. MacMillan Press, New York, NY

Quigley J (1998) Urban Diversity and Economic Growth. Journal of Economic Perspectives 12(2): 127-138.

Romer P (1986) Increasing returns and long-run growth. Journal of Political Economy 94: 5, 1002-1037

Romer P (1990) Endogenous technological change. Journal of Political Economy 98: 71-102

Rosenthal SS, Strange WC (2001) The determinants of agglomeration. Journal of Urban Economics 50: 191-229

Saxenian A (1994) Regional advantage: Culture and competition in Silicon Valley and Route 128. Harvard University Press, Cambridge, MA

Shefer D (1973) Localization economies in SMSAs: A production function approach. Journal of Regional Science 13: 55-64

Schumpeter J (1934) The theory of economic development. Harvard University Press, Cambridge, MA

Trajtenberg M (2002) A penny for your quotes: Patent citations and the value of innovations. In: Patents, citations and innovations. A window on the knowledge economy. The MIT Press, Cambridge MA, London, England

Wagner, JE, Deller SC (1998) Measuring the effects of economic diversity on growth and stability. Land Economics 74(4): 541-560

Varga A (1998) University research and regional innovation. Kluwer Academic Publishers, Boston, MA 


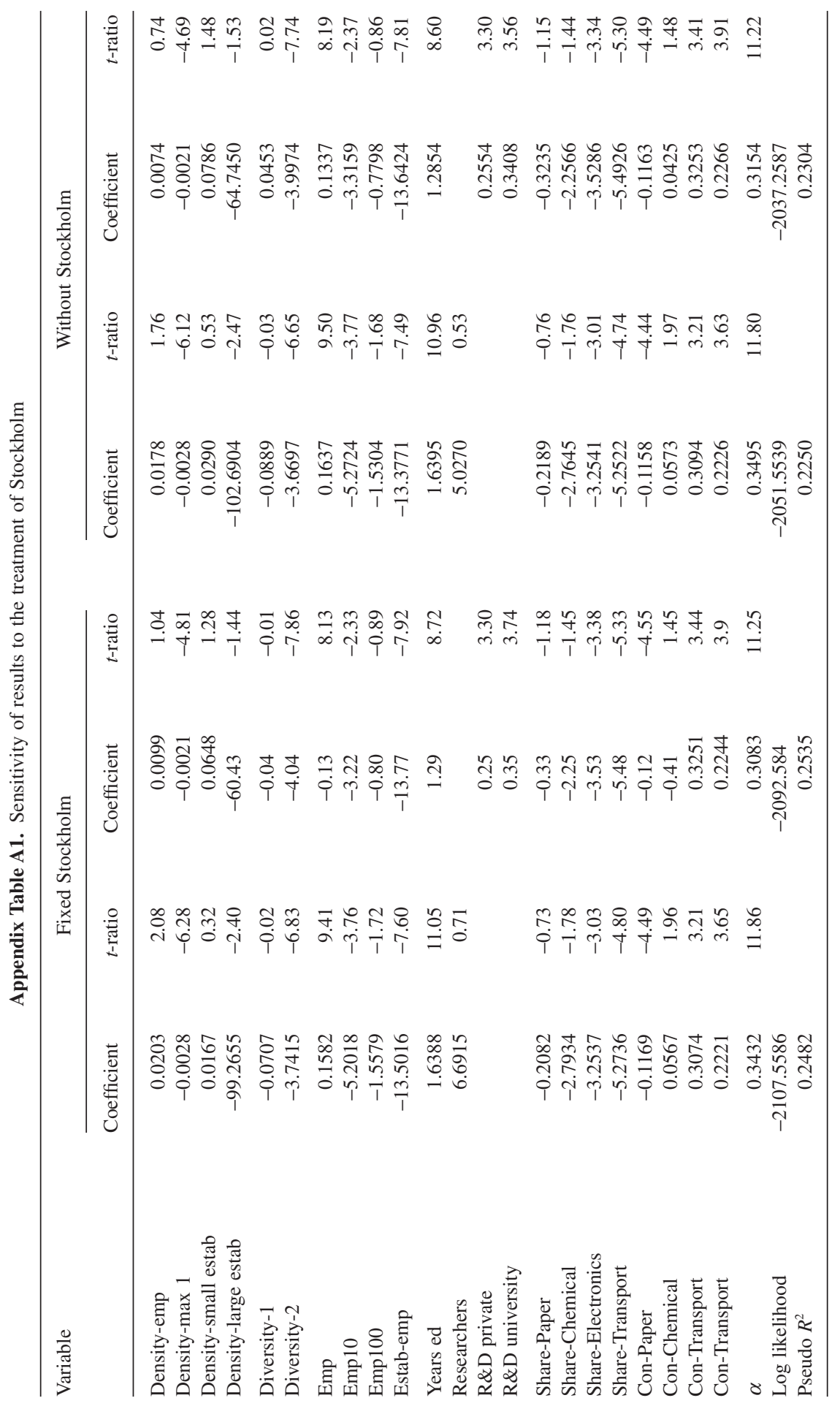

